\title{
Izolált pulmonalis billentyứ részleges hiány (cuspis agenesia) társulása pulmonalis aneurizmával
}

\author{
Hartyánszky István', Rácz Katalin³, Katona Márta', Varga Sándor', \\ Babik Barna², Sélei Ágnes ${ }^{4}$, Bogáts Gábor ${ }^{1}$
}

\author{
Szegedi Tudományegyetem, Szent-Györgyi Albert Klinikai Központ, 'Szívsebészeti Osztály, \\ ${ }^{2}$ Aneszteziológiai és Intenzivterápiás Osztály, ${ }^{3}$ Gyermekgyógyászati Klinika, ${ }^{4}$ Diagnosztika, Szeged \\ Levelezési cím: \\ Prof. dr. Hartyánszky István, e-mail: hartyanszky@hotmail.com
}

\begin{abstract}
A pulmonalis billentyühiány izolált, egy cuspisra terjedő formája ritka kórkép. A keringési viszonyok sajátossága miatt a klinikai tünetek progressziója lassú (arteria pulmonalis törzs aneurizma, pulmonalis regurgitáció) emiatt többnyire nagyobb gyermek-, felnőttkorban kerül észlelésre. 14 éves kisleánynál a tágult pulmonalis törzs eltávolítása után a bal pulmonalis cuspis hiánya, jobb cuspis degeneratív elváltozása miatt a jobb kamra - pulmonalis folytonosság kialakítása homograft beültetéssel történt. Zavartalan posztoperatív szak. 5 hónapos utánkövetésnél normál echokardiográfiás paraméterek.
\end{abstract}

Kulcsszavak: pulmonalis billentyủ részleges hiánya

Isolated congenital absence of a single pulmonary valve cusp associated with pulmonary aneurysm Isolated absence of a single pulmonary valve is extremely unusual. The flow dynamics is very special in this condition resulting in slow progression in clinical findings (significant pulmonary regurgitation, right ventricular enlargement, and dilatation of the main pulmonary artery) hence it is recognised mostly in adolescent and adult age. A 14-year old female was diagnosed with dilated main pulmonary artery, pulmonary incompetence and right ventricular dilatation. At the time of surgery the dilated pulmonary artery and the pulmonary valve (which had normal anterior, a dysplastic right cusp and the left cusp completely absent) were resected and reconstruction was performed using homograft. There were no postoperative complications. The child was seen in the follow-up clinic five months later with normal Echo findings.

Keywords: isolated absence of a single pulmonary valve

A pulmonalis billentyű szerzett betegségei nagyon ritkák. A veleszületett elváltozások (stenosis, insuffitientia) már újszülött-, csecsemőkorban észlelésre és korrekcióra kerülnek, (1 2) ezért említést érdemel, ha a pulmonalis billentyű veleszületett betegsége gyermek-, felnőtt életkorban kerül felismerésre és primer korrekcióra $(3,4,5,6)$. llyen ritka megjelenési forma a billentyü részleges, egy cuspisra terjedő hiánya.

\section{Esetismertetés}

CA. 14 éves külföldi kisleány (Rotary, Gift of Life program keretében) került felvételre a fáradékonysága hátterében levő pulmonalis inszufficiencia és pulmonalis törzs ectasia miatt.

Az echokardiográfiás diagnózist az MR megerösítette. DOP/2D-echokardiográfia: Ventriculo-atrialis és arte- 
rio-ventricularis concordantia. Myocardium kontraktilitása jó, falmozgászavar nem látható. A jobb kamra nagyobb, a septum mozgása ellapult. A jobb pitvar kissé tág. Becsült kisvérköri nyomás 22-28 Hgmm. A kamrai septum ép. A pitvari septumon foramen ovale apertum. A tüdővénák beömlése, aorta eredése, lefutása szabályos. A pulmonalis billentyű vékony, tágult, jelentős regurgitáció látható. $A$ jobb kamrai kiáramlás kissé tágabb. Az arteria pulmonalis törzsön kifejezett tágulat látható. A pulmonalis ágak szabályosak. Kis mitralis prolapsus, insuffitientia nincs. Vaskos bal kamrai ínhúr. PI: 2/4, TI: min. Koronáriák eredése rendben. Ao: 30, BP: 31, BK: 47-27, S: 9-14, HF: 9 mm. Ao gyök: 28-30, AP gyök: 32-33, AP törzs: 52-54 mm.

Vélemény: Szabálytalan pulmonalis billentyű. Arteria pulmonalis törzs jelentős tágulata (ectasia). Relatív pulmonalis stenosis, pulmonalis insuffitientia. Bal kamrai ínhur. Foramen ovale apertum. Mitralis prolapsus (1. ábra).

MR: Szív natív és kontrasztos vizsgálata+angio.

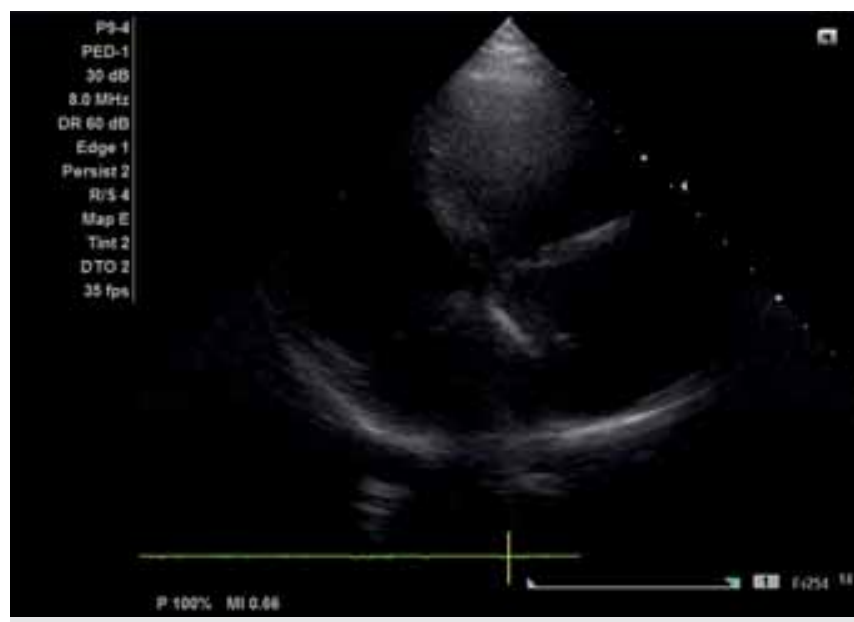

1. A ÁBRA. Négyüregű echokardiográfiás felvétel. Tág jobb kamra látható

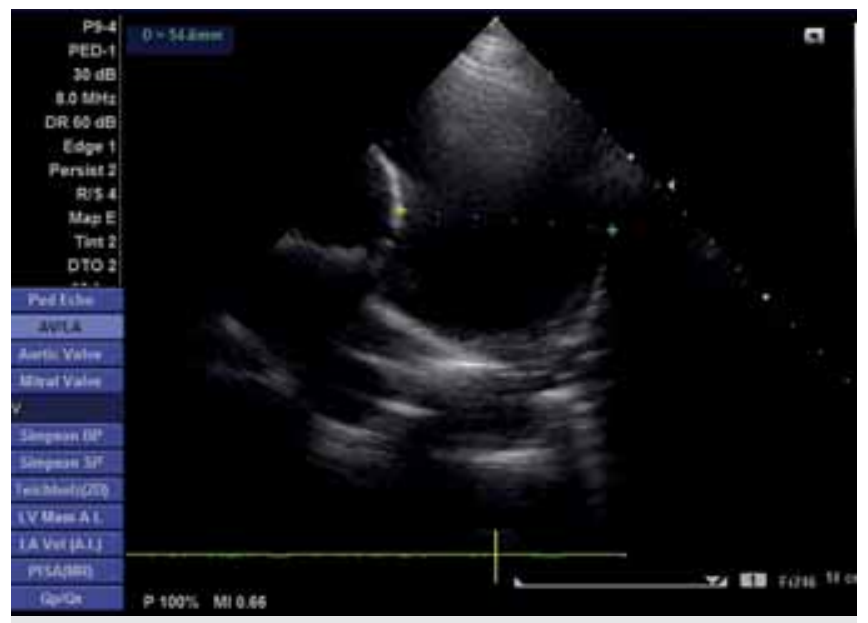

1. B ÁBRA. Nagy érsíkú, keresztmetszeti echokardiográfiás felvétel. Extrém tág ateria pulmonalis törzs látható

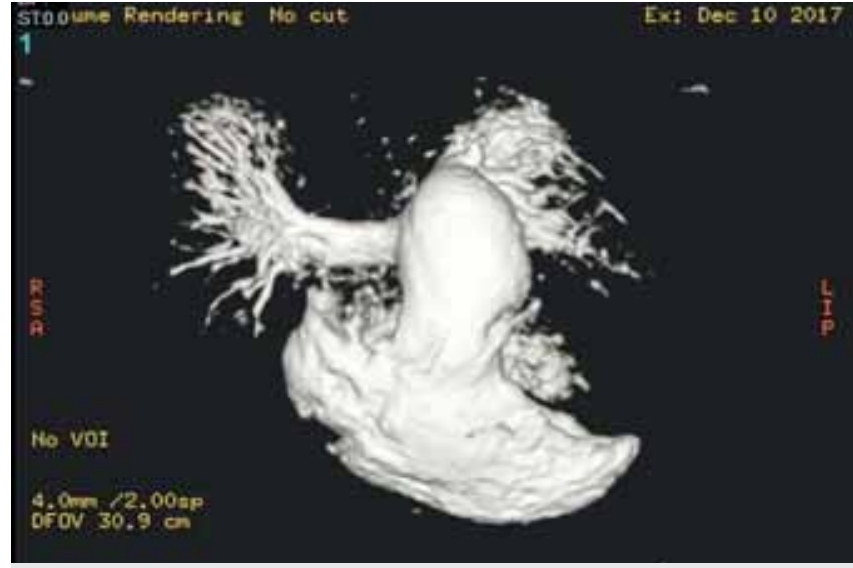

2. ÁBRA. MR-képen a tágult arteria pulmonalis törzs látható

A bal szívfél normál tágasságú, jó globális bal kamra szisztolés funkció. Normál végdiasztolés és végszisztolés volumenek. Jó verővolumen. Normál balkamra-izomtömeg. Szegmentális falmozgászavar nem látható. LVEDV: $107 \mathrm{ml} / \mathrm{m}^{2}$, LVESV: $36 \mathrm{ml} / \mathrm{m}^{2}$, LVEF: $69 \%$, $\mathrm{SV}: 72 \mathrm{ml} / \mathrm{m}^{2}, \mathrm{LV}_{\text {mass }}: 79 \mathrm{~g}$.

A jobb kamra tágabb, fala trabekularizált. A jobb pitvar normál tágasságú. Pulmonalis insuffitientiára utaló jet. A pulmonalis arteria aneurizmatikusan tágult, 43-45 mm legnagyobb átmérője. A jobb pulmonalis artéria tágassága, lefutása szabályos. A bal pulmonalis artéria lényegében az aneurizmatikus tágulatból azonnal kettéoszlik. A tüdők vaszkularizációja szabályos, oldalkülönbség nincs. A mellkasi aorta szabályos lefutású, és tágasságú. RVEDV: $144 \mathrm{ml} / \mathrm{m}^{2}$, RVESV: $54 \mathrm{ml} / \mathrm{m}^{2}$, RVEF: 57\%, RVSV: $70 \mathrm{ml} /$ $\mathrm{m}^{2}$. Vélemény: Pulmonalis arteria aneurizmatikus tágulata. Tágult jobb kamra. Pulmonalis insuffitientia (2. ábra).

\section{Mútét}

Terv

Pulmonalis billentyűplasztika, pulmonalis törzs reszekció+mủérbeültetés. Extracorporalis keringésben, dobogó szíven történt az aneurizmatikusan tágult (45-50 mm) pulmonalis törzs eltávolítása. Exploráció során a pulmonalis billentyű septalis cuspisa ép, vékony, a bal cuspis teljesen hiányzik, a jobb cuspis degeneratív, megvastagodott, tágult (3. ábra). Plasztikai megoldás nem jöhet szóba, ezért a billentyű eltávolítása és annulus nagyobbítása után 27 mm-es pulmonalis homograft implantálása jelentette a jobb kamra - pulmonalis folytonosság helyreállítását.

Zavartalan posztoperatív szak után 10. nap távozik otthonába. Öthónapos ellenőrző echokardiográfiás vizsgálaton pulmonalis stenosis, regurgitáció nem észlelhető, jobb kamra normálnagyságú.

\section{Megbeszélés}

A pulmonalis billentyű izolált fejlődési rendellenességei ritkák, általában a jobb kamra kifolyási pálya, pulmona- 


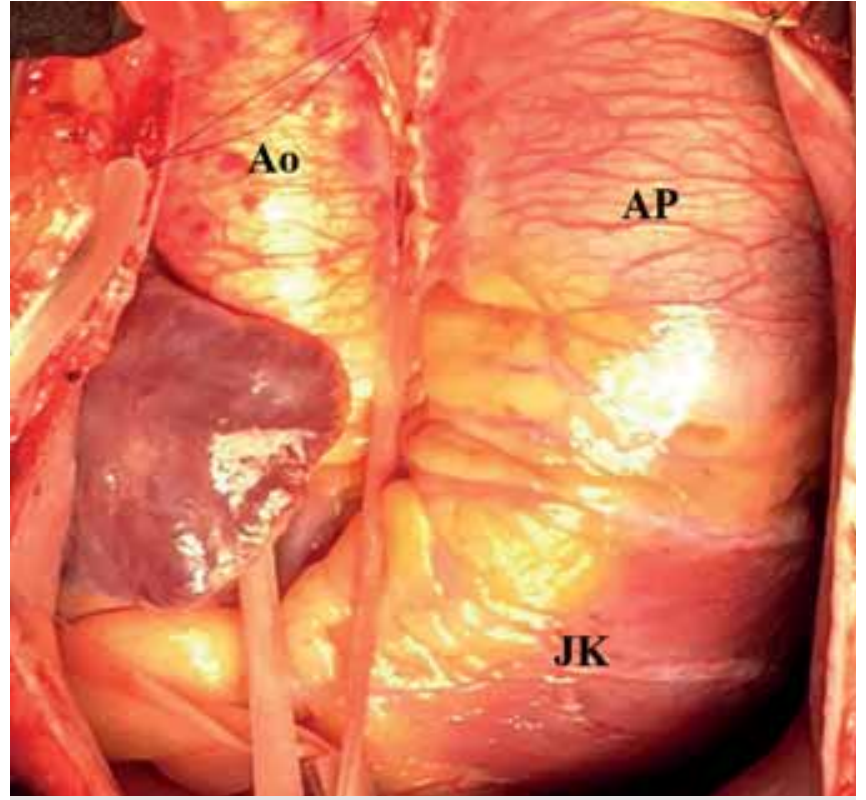

3. A ÁBRA. Tágult arteria pulmonalis törzs intraoperatív képe. Ao: aorta ascendens, AP: arteria pulmonalis törzs, JK: jobb kamra

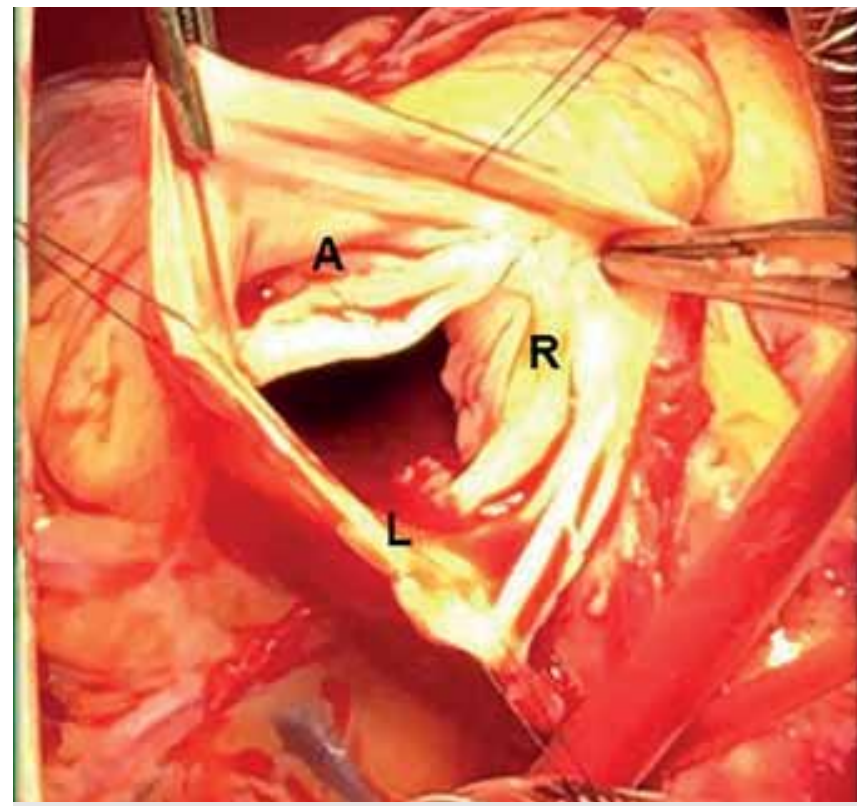

3. B ÁBRA. Pulmonalis billentyű intraoperatív képe: A. Normál anterior cuspis, R. Diszplasztikus jobb cuspis, L. Hiányzó bal cuspis lis annulus fejlődési zavaraihoz társulva (hiánya - truncus arteriosus communis, hypoplasiája - Fallot-tetralogia stb.) jelentkeznek. Gyakori a billentyűstenosis, súlyos esetben atresia, ép kamrai sövénnyel, esetleg jobb kamra részleges hypoplasiaval. Az annulus és az arteria pulmonalis ágrendszer ilyenkor általában normális nagyságú. Balloon-katéteres tágítás, vagy a sebészi valvulotomia jelenti a betegség megoldását.

A pulmonalis billentyühiány ritka kórkép. Két formában jelentkezik:

1. a billentyú teljes hiányával $(1,2)$;

2. a billentyű részleges, egy-két cuspisra terjedő hiányával (3-6).

1. A komplett forma esetén az annulus szükebb gyürüt formál, amelyben a billentyű göcsörtös formában, nyomokban található meg. Ez az anatómiai megjelenés speciális keringési, áramlási viszonyokat hoz létre: az annulus szűkületet okoz, a billentyühiány pedig jelentős regurgitációt eredményez. A speciális „to-and fro” áramlás a pulmonalis artériák különböző fokú tágulatát okozza, legsúlyosabb esetekben a többszörösére tágult, aneurizmaszerű pulmonalis erek jelentősen öszszenyomhatják a bronchusokat is. E kórkép önállóan nem fordul elő, mindig társul Fallot-tetralogiához. Ez a társulás súlyosbítja a klinikai tüneteket, mert a kamrai septumdefektuson keresztüláramló vér miatt emelkedhet a perctérfogat, amely a pulmonalis szájadékon átfolyik. Ezért nem csoda, hogy a legsúlyosabb esete- ket már születés után, újszülöttkorban sürgősen meg kell operálni (1, 2). A mútéti megoldás a szívhiba korrigálása (kamrai septumdefektus zárása, pulmonalis annulus tágítása monocusp transannularis folttal, vagy billentyűs grafttal) mellett az extrém tág arteria pulmonalis ágak reszekálása, plasztikázása, plicálása, valamint szükség esetén a bronchusok stenttel való tágítása. A kórkép enyhébb eseteit is már csecsemőkorban korrigálni szükséges.

2. A pulmonalis billentyű részleges hiánya még ritkábban észlelhető. Ilyenkor a bal cuspis nem fejlődik ki, csökevényes, és a jobb cuspison kialakult degeneratív elváltozások is gátolhatják a billentyü müködését. $A z$ így kialakult anatómiai kép is speciális áramlási viszonyokat teremt, amelynek eredményeként a pulmonalis törzsön aneurizma szerü tágulat alakul ki, amelyhez súlyosabb esetben a pulmonalis ágak tágulata is társulhat. Miután a folyamat lassan progrediál, a kórkép általában gyermek-, felnőttkorban kerül észlelésre, melyre a pulmonalis regurgitáció-, jobbkamra-tágulat, illetve a pulmonalis aneurizma hívja fel a figyelmet. Műtéti megoldást az anatómiai elváltozások szabják meg. Ha lehet, törekedni kell a billentyü plasztikai korrigálására, de szükség esetén a cseréje jelenti a megoldást $(3,4,5,6)$. A pulmonalis törzs tágulatát lehet plasztikázni, vagy reszekálni és pótolni müérrel vagy homografttal. A két megoldás kombinálásakor lehetséges billentyű plasztika+pulmonalis érplasztika, vagy biológiai

\section{Rövidítések:}

Ao: aorta; AP: arteria pulmonalis; BK: bal kamra; Bp: bal pitvar; HF: hátsó fal; LVEDV: bal kamra végdiasztolés volumen; LVEF: bal kamra ejekciós frakció; LVESV: bal kamra végszisztolés volumen; LV: mass bal kamra izomtömeg; MI: mitralis insuffitientia; PI: pulmonalis insuffitientia; S: septum; SV: verővolumen; RVEDV: jobb kamra végdiasztolés volumen; RVEF: jobb kamra ejekciós frakció; RVESV: jobb kamra végszisztolés volumen; RVSV: jobb kamra verővolumen 
mübillentyü-beültetés+műérpótlás, vagy homograft-beültetéssel megoldani a billentyű és pulmonalis artéria pótlását.

Betegünknél a pulmonalis billentyű plasztikázását és a tágult pulmonalis ér műérrel való pótlását terveztük. Feltárásnál szembesültünk azzal, hogy a hiányzó bal cuspis mellett a jobb cuspis degeneralódótt, így plasztikai megoldás nem jöhetett szóba. A leány várható életmódja (férjhezmenés, szülés stb.) miatt döntöttünk az antikoagulációs terápiát nem igénylő homograft beültetése mellett. Ez kisebb megterhelést jelent, mint a biológiai billentyű+múér beültetése, és a későbbiekben esetlegesen kialakuló homograft-elégtelenség esetén technikailag könnyebben kivitelezhető transzkatéteres úton a Melody-billentyủ beültetése.

\section{Következtetések}

Esetünk is megerősíti annak a szükségességét, hogy a veleszületett szívhibás gyermekek és felnőttek kezelésére, kongenitális szívhibákat ismerő, megfelelő képzésü és tapasztalatú szívsebészek, gyermekkardiológusok, kardiológusok alkotta centrumok álljanak rendelkezésre.

Irodalom

1. Hartyánszky I, Prodán Zs, Kádár K, et al. Rare Heart Defects Associated with Tetralogy of Fallot with Absent Pulmonary Valve. Surgical Challenges and Results. $4^{\text {th }}$ World Congress of Pediatric Cardiology and Cardiac Surgery. Buenos Aires, Argentina 2005.

2. Hartyánszky I, Kádár K, Oprea V, et al. Pulmonalis billentyű agenesia, Fallot-tetralogia sikeres sebészi kezelése újszülöttkorban. Magyar Gyermekkardiológiai Szekció Tudományos Ülése Siófok 2000. 3. Attanawanich S, Khowsathit P, Withurawanit W. Correction of Absent Pulmonary Valve Syndrome Using a Pericardial Valved Conduit. Asian Cardiovascular and Thoracic Annals September 1, 2002 Case Report doi: 10.1177/021849230201000321

4. Sayger $P$, Lewis $M$, Arcilla $R$, et al. Isolated congenital absence of a single pulmonary valve cusp. Pediatr Cardiol 2000; Sep-Oct; 21(5): 487-9. doi: 10.1007/s002460010118

5. Kőszegi Zs, Homoródi N, Bódi A, et al. Giant Pulmonary Aneurysm Associated With Pulmonary Valve Agenesia. Circulation 2005; 112 : 263-264. https://doi.org/10.1161/CIRCULATIONAHA.104.508010

6. Nassar MS, Anderson D. Absence of Single Pulmonary Valve Cusp. J Card Surg 2015; 30: 459-460. doi: 10.1111/jocs.12484 